\title{
REVALIDATION OF GENUS CHIONAEMA HERRICH SCHÄFFER (LITHOSIINAE: ARCTIIDAE: LEPIDOPTERA) ALONG WITH GENETALIC STUDIES ON SIX SPECIES FROM NORTHERN AND NORTHEASTERN INDIA
}

\author{
Amritpal Singh Kaleka
}

Department of Zoology, Punjabi University, Patiala, Punjab 147002, India.

\begin{abstract}
Detailed morphological studies, including the male and female genitalic structures revealed that the type species i.e. puella Drury of the genus Chionaema Herrich Schäffer is altogether different from detrita Walker, the type species of genus Cyana Walker. Accordingly, the genus Chionaema with the type species puella Drury is being revived. The genitalic features of five other species i.e. bellissima (Moore), catorhoda Hampson, obliquilineata Hampson, dudgeoni Hampson and alborosea (Walker) of genus Chionaema have also been critically examined. These species completely conform to the characterization of type species of genus Chionaema.
\end{abstract}

\section{Keywords}

Chionaema, Cyana, type species, genitalia

\author{
ACC. SC - Accessory Sac \\ AM - Ampulla \\ CO - Costa \\ CRP.BU - Corpus bursae \\ DU.BU - Ductus bursae \\ GP - Genital plate \\ $M$ - Medial vein \\ PO.APO - Posterior apophyses \\ SA - Saccus \\ SIG - Signum \\ TG - Tegumen \\ UN - Uncus \\ VLA - Valvula
}

\section{Abbreviations}

\author{
AED - Aedeagus \\ ANT.APO - Anterior apophyses \\ CRN - Cornuti \\ $\mathrm{Cu}$ - Cucullus \\ DU.EJ. - Ductus ejaculatoris \\ JX - Juxta \\ PAP.A - Papilla analis \\ $\mathrm{R}$ - Radial vein \\ Sc+R - Subcosta and radial vein \\ SL - Sacculus \\ TRA - Transtilla \\ VIN - Vinculum
}

\section{Introduction}

While conducting surveys in northern and northeastern India, as many as forty four specimens of six species were collected and identified as puella Drury, bellissima Moore, catorhoda Hampson, obliquilineata Hampson, dudgeoni Hampson and alborosea Walker under genus Cyana with the help of relevant literature (Hampson, 1894, 1900; Arora \& Chadhury, 1982; Kishida, 1991). While dealing with genus Chionaema, Hampson
(1900, 1914) listed Cyana as one of its synonyms. Roepke (1944) reversed this taxonomic arrangement with a hint that the type species of genus Cyana i.e detrita Walker may become separated generically from those species characterized by their white ground colour with red cross lines or bands on forewing. The studies of different morphological structures including genitalia indicates that the type species of Chionaema i.e. puella Drury is altogether different from type species of genus Cyana with 
respect to uncus, valvula and cucullus of male genitalia and ductus bursae of female genitalia, Watson et al. (1980) have listed both the genera with their type species in their volume, Thus both these genera are distinct. Accordingly other five species conform to the characterization of type species of Chionaema and form a natural group. A key to differentiate both the genera has been formulated and key to the species of genus Chionaema, studied during present investigations is also given.

\section{Observations}

Genus Chionaema Herrich Schäffer

Herr. Schäffer, 1855, Syst. Bearbeitung Schmett. Eur. 6: 100-101

\section{Type species: Chionaema puella Drury}

\section{Distribution}

Throughout India; Africa; China; Indonesia; Myanmar; Sri Lanka

\section{Diagnostic features}

Labial palpus slender and upturned, not reaching lower level of frons. Antenna simple, ciliated. Hind tibia with two pair of spurs. Forewing narrow; male with a more or less strongly developed fringe of hair from middle of costa on upper side and lobe on underside which may be uni-lobate, bi or trilobate; veins $\mathrm{R}_{3}-\mathrm{R}_{5}$ stalked; vein $\mathrm{M}_{1}$ originating from upper angle, absent in female; $M_{2}$ usually above lower angle, absent in male; $M_{3}$ from lower angle of cell; $\mathrm{Cu}_{1}$ arising from before or from lower angle of cell; $\mathrm{Cu}_{2}$ from near middle of cell. Hindwing with vein $\mathrm{Sc}+\mathrm{R}_{1}$ from or beyond middle of cell; $\mathrm{M}_{1}$ and Rs usually stalked from upper angle; $\mathrm{M}_{2}$ arising from above lower angle of cell; $\mathrm{M}_{3}$ and $\mathrm{Cu}_{1}$ usually stalked from lower angle of cell; $\mathrm{Cu}_{2}$ from beyond middle of cell. Male genitalia with uncus simple, narrow, curving ventrally; tegumen well developed; vinculum broad ending into $\mathrm{U}$ or $\mathrm{V}$-shaped saccus, inner wall of saccus may be produced to form hump. Valva elongate; sacculus and costa well differentiated; valvula usually shorter than cucullus with a beaked or pointed tip; cucullus semi-sclerotized with rounded tip; juxta well developed; transtilla prominent; aedeagus of moderate size, vesica armed with well defined cornuti. Female genitalia with corpus bursae of variable size, usually membranous; signum may be present or absent; ductus bursae quite long, anterior half slightly or well sclerotized, posterior half membranous; anterior apophyses smaller than posterior ones; papilla analis of moderate size, semi-sclerotized.

\section{Chionaema bellissima (Moore) \\ (Figs. 1-4)}

Bizone bellissima Moore, 1878, Proc. Zool. Soc. 1878: 27; Kirby, 1892, Cat. Het., 1: 301; Hampson, 1894, Moths Ind. 2: 61; id., 1900, Cat. Lep. Phal., 2: 319.

\section{Material examined}

One male, 29.ix.1994, Jowaii, Jaintia Hills, Meghalaya; one male, 2.x.1994, Cherapunjee, Meghalaya; one male, 08.vi.1995, Choukori, Uttaranchal; one male, 29.iv.1995, Kurseong, West Bengal.

\section{Wing expanse (half)}

Male: $19-23 \mathrm{~mm}$.

\section{Distribution}

Meghalaya: Jowaii, Jaintia Hills, Cherapunjee; Sikkim; Uttaranchal: Mussorrie Town, Choukuri; West Bengal: Kurseong.

\section{Diagnostic features}

Male genitalia: Uncus short and narrow, tapering towards tip; tegumen broad at base of uncus; vinculum well developed, Ushaped, broad at base, narrow towards tegumen; saccus with its outer wall straight and inner produced out-wardly. Valva broad, sacculus and costa defined; cucullus of equal width, a sclerotized patch at its base present; valvula highly sclerotized near tip, ending into a prominent spine; juxta flask-shaped, theca crested; transtilla defined. Aedeagus with both of its walls well sclerotized, narrow anteriorly, broad and rounded posteriorly; vesica armed with a scobinate patch in middle, spine-like cornuti and densely packed spines at the distal end.

\section{Female genitalia: Not examined.}

\section{Remarks}

Reporting of this species from above mentioned localities of Meghalaya and West Bengal are its additional distributional areas in northeastern India.

\section{Chionaema catorhoda Hampson}

(Figs. 5-8)

Hampson, 1897, Journ. Bomb. Nat. Hist. Soc. 11: 296; id. 1900, Cat. Lep. Phal 2: 297.

\section{Material examined}

One male, 30.ix.1995, Jatinga, North Cachar Hills, Assam

Wing expanse (half)

Male: $13 \mathrm{~mm}$ 

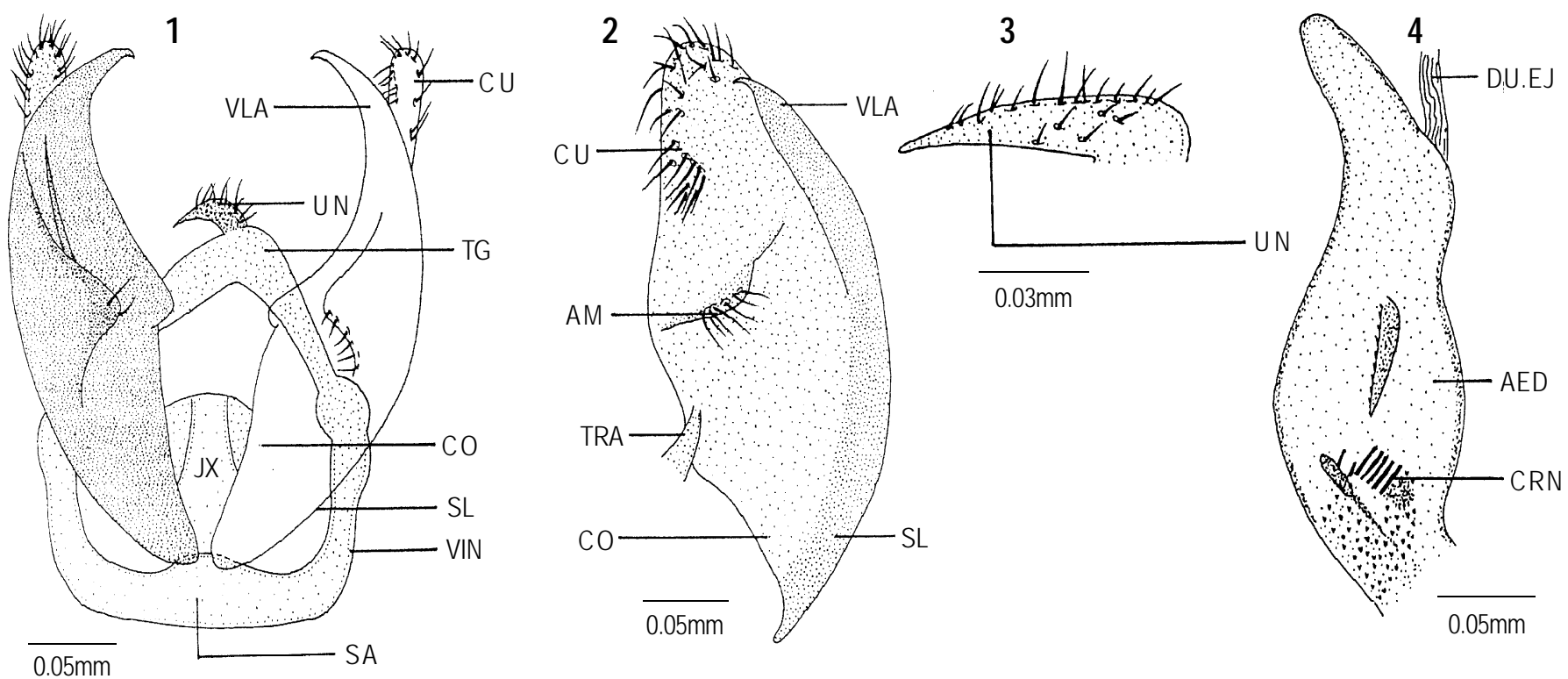

Figures 1-4. Chionaema bellissima Moore

1. Male genitalia; 2. Valva - left inner view; 3. Uncus - enlarged; 4. Aedeagus
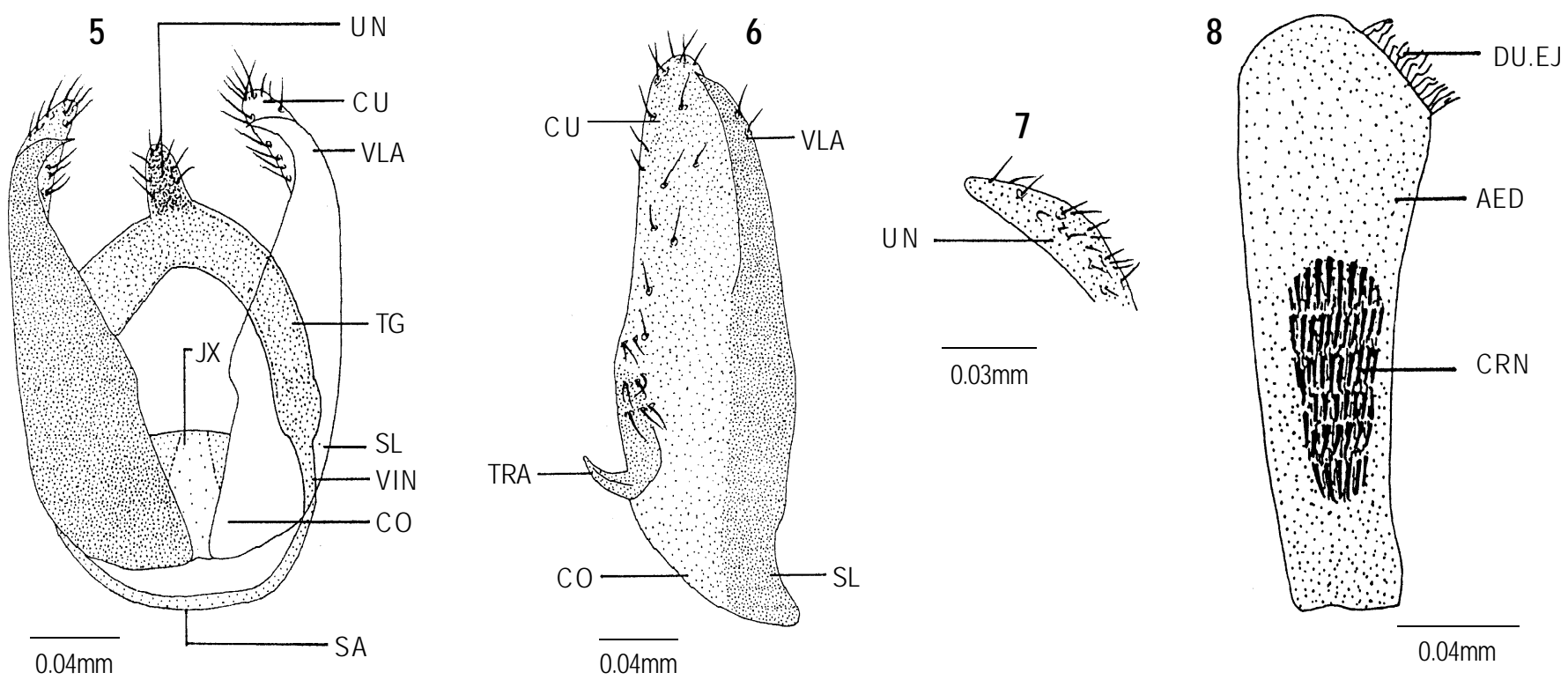

Figures 5-8. Chionaema catorhoda Hampson

5. Male genitalia; 6. Valva - left inner view; 7. Uncus - enlarged; 8. Aedeagus 


\section{Distribution}

India: Assam: Jatinga, North Cachar Hills; Meghalaya: Khasi Hills.

Elsewhere: Myanmar.

\section{Diagnostic features}

Male genitalia: Uncus narrow, reduced, with rounded tip, semisclerotized, dorsally setosed; tegumen broad, semi-sclerotized, vinculum shorter than tegumen, ending into U-shaped narrow walled saccus; saccus well sclerotized. Valva long and narrow, with sacculus and costa defined; cucullus extending slightly beyond valvula, with a setosed rounded tip; valvula with sharply pointed tip; juxta flask-shaped, theca slightly crested; transtilla bar-like. Aedeagus short, with broad, rounded anterior end, narrowing towards distal end; vesica armed with a long patch of densely packed spines from middle and beyond this patch with small denticles.

\section{Female genitalia: Not examined}

\section{Remarks}

This species is newly recorded from Jatinga (Assam).

\section{Chionaema obliquilineata Hampson}

(Figs. 9-13)

Hampson., 1900, Cat. Lep. Phal., 2: 299.

\section{Material examined}

One male, 12.ix.1991, one female 14.ix.1991, one female; 23.ix.1993, Jatinga, North Cachar Hills, Assam.

\section{Wing expanse (half)}

Male: $11 \mathrm{~mm}$

Female: $14 \mathrm{~mm}$

\section{Distribution}

Assam: Jatinga, North Cachar Hills; Sikkim

\section{Diagnostic features}

Male genitalia: Uncus small, highly curved, broad at base, narrowing towards middle and tapering at distal end; tegumen long, narrowing towards vinculum, broad near base of uncus; vinculum half the size of tegumen, with lateral sides slightly produced; saccus reduced and U-shaped. Valva simple, with costa and sacculus slightly defined; valvula ending into a spinelike structure distally; cucullus extending slightly beyond valvula; juxta broad, flask-shaped, theca crested; transtilla barlike. Aedeagus rounded and broad anteriorly, with both of its wall equally sclerotized; vesica with a patch of densely packed spines in middle, with a large number of denticles around the patch and in posterior half.
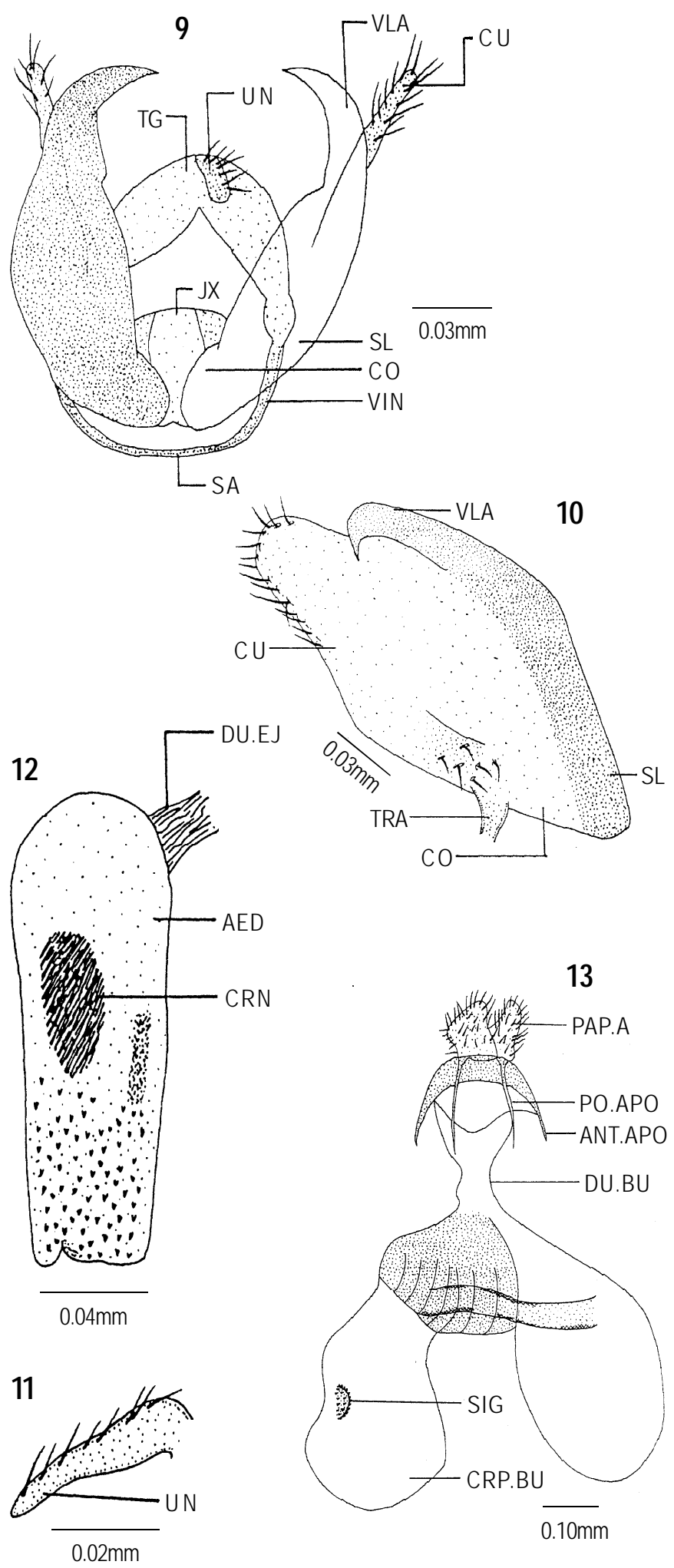

Figures 9-13. Chionaema obliquilineata Hampson 9. Male genitalia; 10. Valva - left inner view; 11. Uncus enlarged; 12. Aedeagus; 13. Female genitalia 
Female genitalia: Corpus bursae oblong, rounded anteriorly, constricted in middle, membranous; a single clad-like signum present; ductus bursae small, broad anteriorly, slightly sclerotized, narrowing posteriorly and membranous; anterior apophyses half length of posterior ones, both pairs narrow with their apices pointed; papilla analis triangular setosed with micro and macrosetae.

\section{Remarks}

Collection of this species from Jatinga is its first record from Assam.

\section{Chionaema dudgeoni Hampson}

(Figs. 14-18)

Hampson, 1894, Moths Ind., 2: 492; id., 1895, Trans. Ent. Soc., 1895: 293; id.1896, Journ. Bomb. Nat. Hist. Soc., 11: 296; id. 1900, Cat. Lep. Phal., 2: 321.

\section{Material examined}

One male, 26.ix.1995, one female, 27.ix.1995, one female, one male, 30.ix.1995, Jatinga, North Cachar Hills, Assam.

\section{Wing Expanse (half)}

Male: $13 \mathrm{~mm}$

Female: $17 \mathrm{~mm}$

\section{Distribution}

India: Assam: Jatinga, North Cachar Hills; Meghalaya: Khasi Hills; Sikkim.

\section{Diagnostic features}

Male genitalia: Uncus of moderate size, curved, tip beak-like; tegumen with both of its arms broad at base of uncus, narrow towards vinculum; vinculum shorter than tegumen, well sclerotized; saccus small, U-shaped. Valva simple with sacculus and costa marked; cucullus with a median sclerotized projection, produced into a rounded setosed patch; juxta long, gradually tapering towards distal end; transtilla defined. Aedeagus with its tip slightly produced and rounded, both of its walls well sclerotized; vesica armed with two patches bearing number of densely packed cornuti.

Female genitalia: Corpus bursae oval, membranous; signum absent; ductus bursae membranous; accessory sac present; both pair of apophyses with their apices pointed, anterior apophyses shorter than posterior apophyses; papilla analis triangular and broad, fringed with short and long setae.

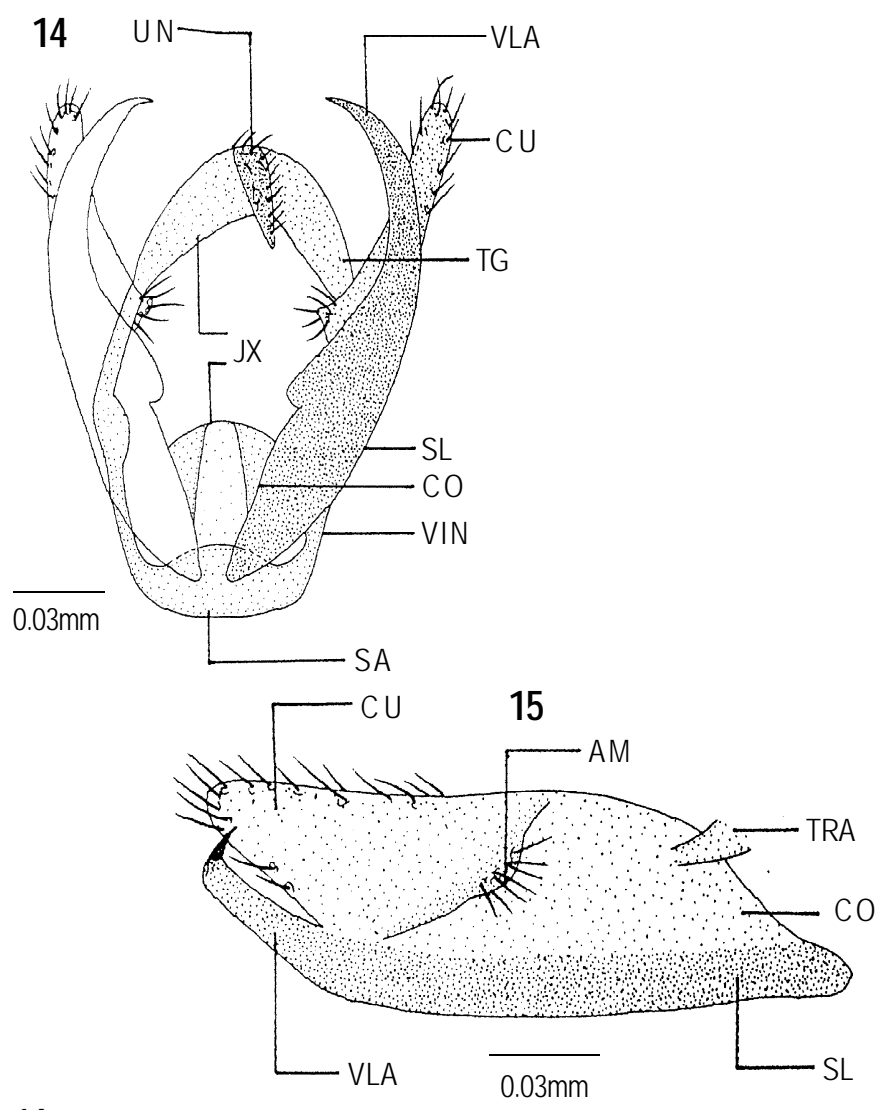

16
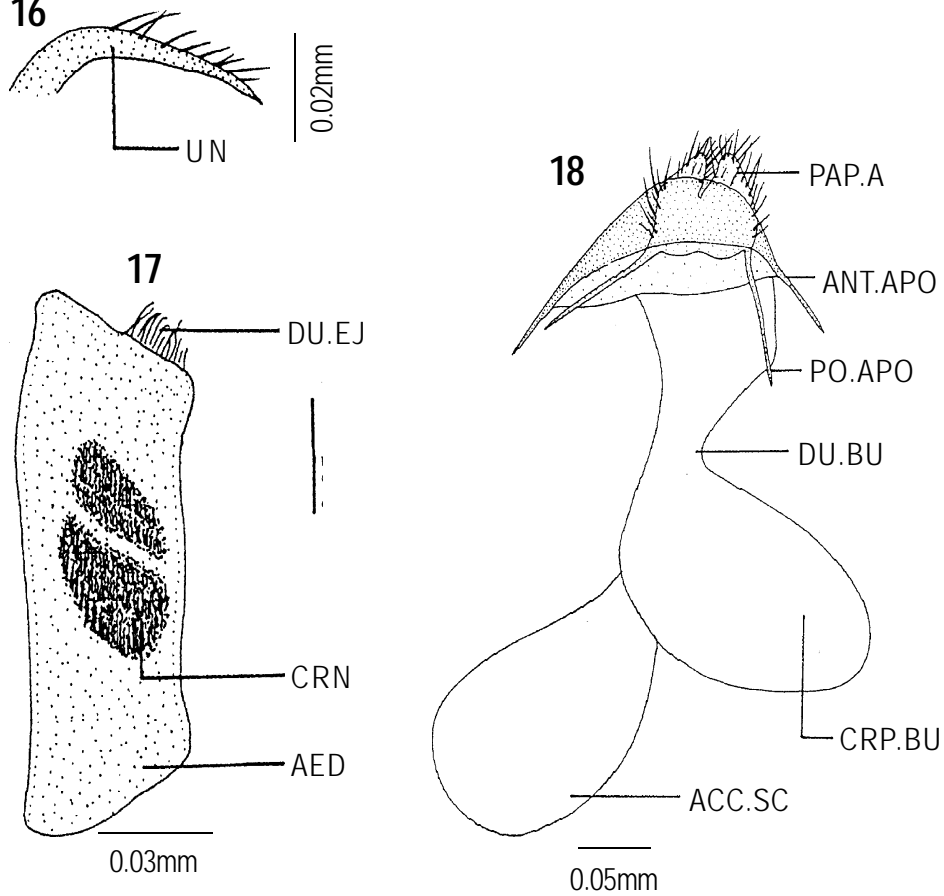

Figures 14-18. Chionaema dudgeoni Hampson

14. Male genitalia; 15. Valva - right inner view; 16. Uncus enlarged; 17. Aedeagus; 18. Female genitalia 


\section{Chionaema puella Drury}

(Figs. 19-23)

Drury, 1773, III. Ex. Ent., 2: 403; Kirby, 1892, Cat. Het. 1: 302; Hampson., 1894, Moths Ind., 2: 57; id. 1900, Cat. Lep. Phal., 2: 298.

\section{Material examined}

Three females, 07.vii.1991, one female, 08.vii.1991, two females, four males, 31.vii.1994, one male 15.vii.1991, one female, 28.ix.1991, Solan, Himachal Pradesh; one female, 1.viii.1994, Nauni, Himachal Pradesh; one female, 9.ix.1995, Macleodganj, Himachal Pradesh; one femlae, 11.vi.1994, two females, two males, 12.vi.1994, Mussorrie, Uttaranchal; one female, two males, 13.vi.1994, Kempty Falls, Uttaranchal; one female, 14.vi.1994, Chakrata, Uttaranchal; three females, 28.vii.1994, Kud, Jammu and Kashmir; one male, 30.viii.1994, Ramanagar, Jammu and Kashmir; one female, 28.viii.1994, Patnitop, Jammu and Kashmir.

\section{Wing expanse (half)}

Male: $14 \mathrm{~mm}$

Female: $17 \mathrm{~mm}$

\section{Distribution}

Himachal Pradesh: Macleodganj, Nauni, Solan, Shimla, Dalhousie;
Jammu and Kashmir: Kud, Ramanagar, Patnitop; Maharashtra: Kangra, Ambala, Mumbai; Tamil Nadu: Nilgiri Hills; Uttaranchal: Kemty Falls, Mussourie, Chakrata

Male genitalia: Uncus short, obliquely curved at base, with setosed tip; tegumen long and narrow; vinculum shorter than tegumen; saccus broad, with both walls narrow and cup-shaped. Valva simple; costa and sacculus ill defined; valvula moderately sclerotized, with its distal end sharply pointed; cucullus large, with its tip rounded. Aedeagus small and broad, with both of its walls slightly but equally sclerotized; vesica without any cornutus.

Female genitalia: Corpus bursae large, globular, membranous proximally, with distal part heavily sclerotized; a pair of crescentiform signa; ductus bursae small and membranous; apophyses narrow with their apices pointed; anterior aophyses less than half length of posterior ones; papilla analis broad, setosed with a fine fringe of large number of micro and few macro setae.

\section{Remarks}

Collection of the present species from above mentioned localities are its additional distributional areas.
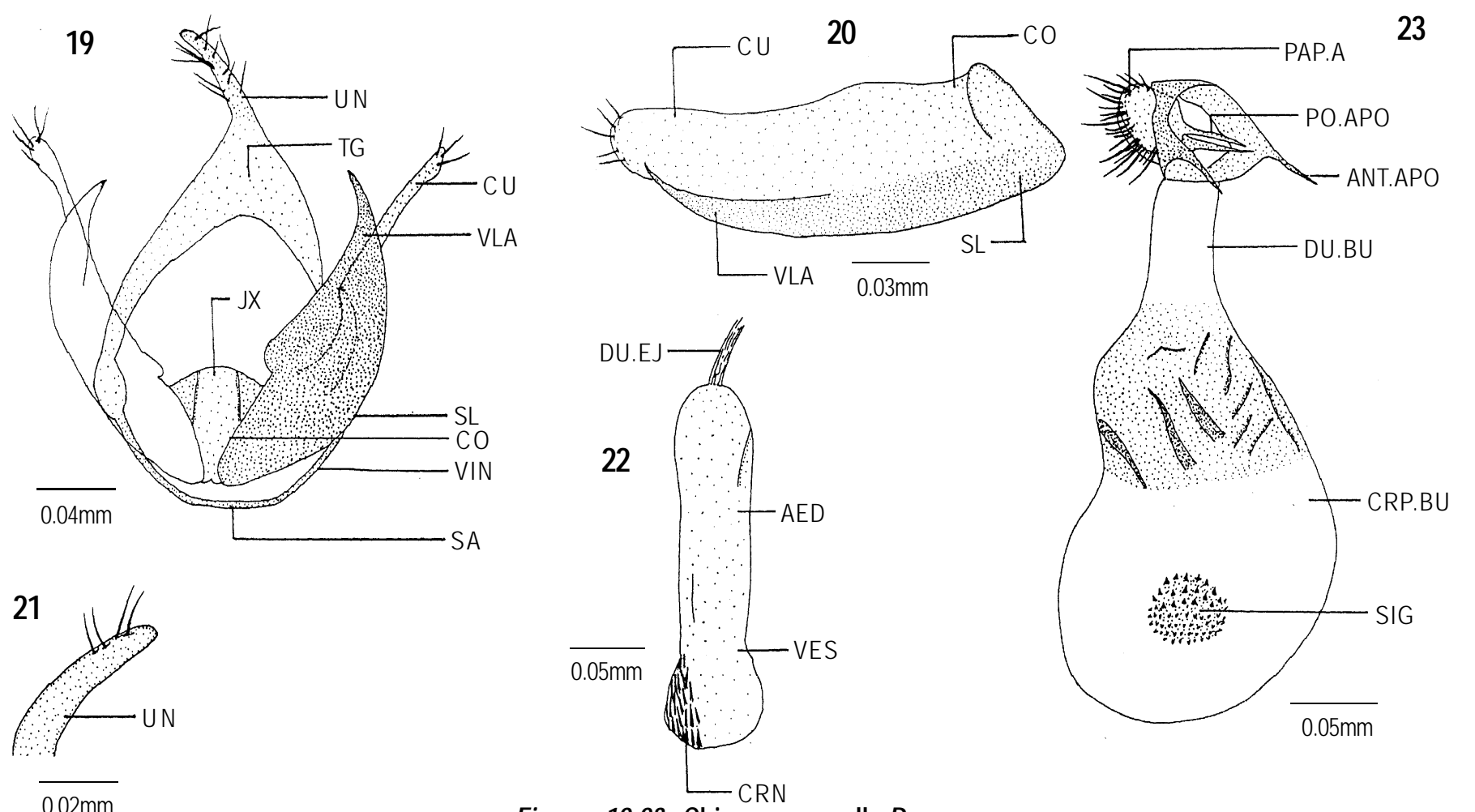

$0.02 \mathrm{~mm}$

Figures 19-23. Chionaema puella Drury

19. Male genitalia; 20. Valva - right inner view; 21. Uncus - enlarged; 22. Aedeagus; 23. Female genitalia 

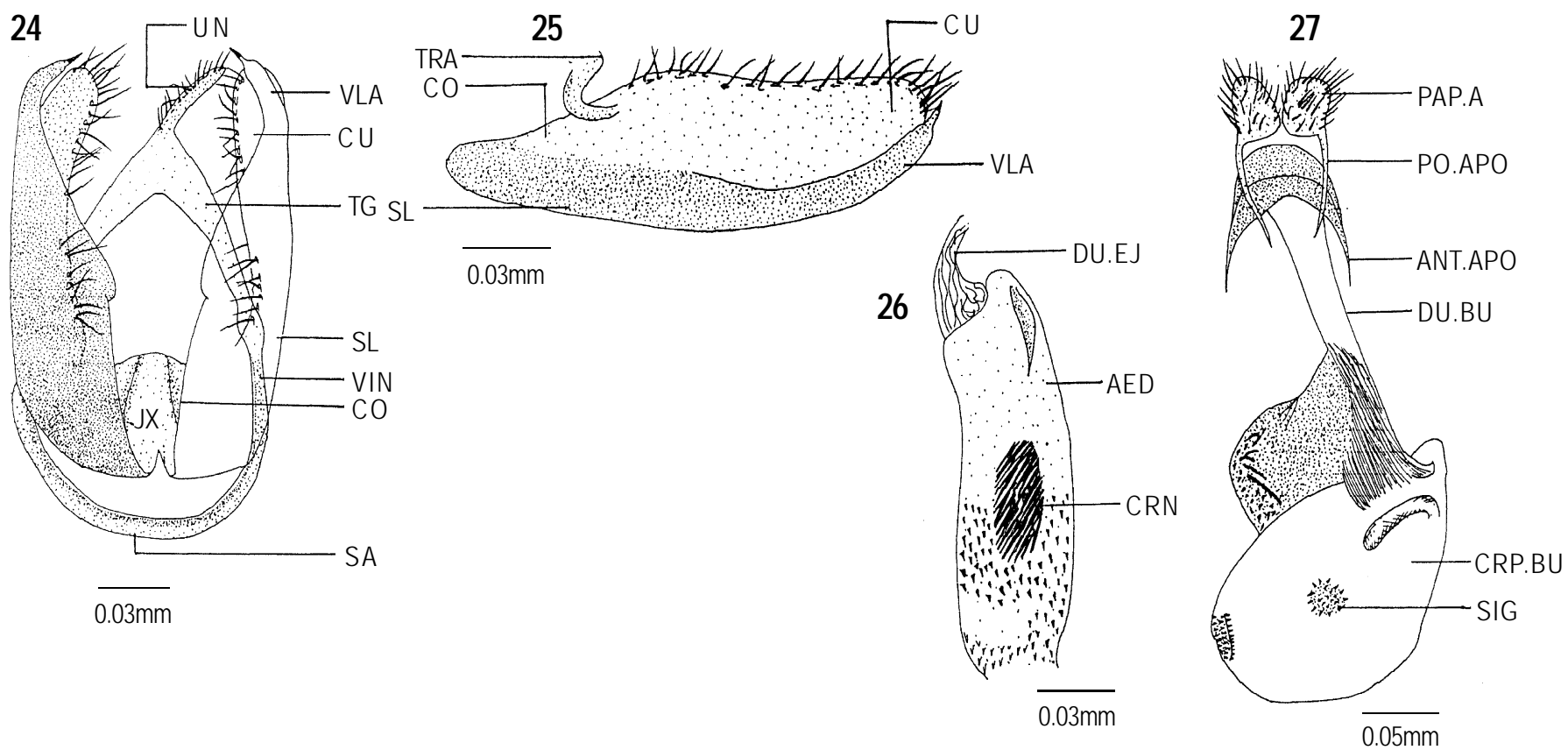

Figures 24-27. Chionaema alborosea Walker

24. Male genitalia; 25. Valva - left inner view; 26. Aedeagus; 27. Female genitalia

\section{Chionaema alborosea (Walker)}

(Figs. 24-27)

Lithosia alborosea Walker., 1864, Cat. Lep. Het., 31: 230; Kirby, 1892,Cat. Het., 1: 302; Hampson., 1894, moths Ind., 2: 56 \& 4: 492; id, 1900, Cat. Lep. Phal. 2: 298-299.

\section{Material examined}

Two males, 29.ix.1994, one female, 30.ix.1994; one female, 02.x.1994, Jatinga, North Cachar Hills, Assam; Cherapunjee, Meghalaya.

\section{Wing expanse (half)}

Male: $13 \mathrm{~mm}$

Female: $15 \mathrm{~mm}$

\section{Distribution}

India: Assam: Jatinga, North Cachar Hills; Meghalaya: Cherapunjee; Sikkim

Elsewhere: Myanmar.

Male genitalia: Uncus short, curved, tip rounded, semisclerotized, dorsally setosed; tegumen slightly sclerotized, longer than vinculum; vinculum U-shaped; saccus reduced. Valva small, sacculus and costa defined; valvula well developed with a sharply pointed small spine-like distal end; cucullus ending at the same level of valvula; juxta broad, well developed; transtilla bar-like. Aedeagus small, with rounded anterior end; vesica armed with a patch of densely packed cornuti in middle.

Female genitalia: Corpus bursae oval, membranous; a pair of signa present; ductus bursae broad anteriorly, narrow posteriorly, anterior half with sclerotized lining; anterior apophyses small, sharply produced into narrow apices; posterior apophyses much longer than anterior apophyses and with pointed ends; papilla analis broad, setosed with fine setae.

\section{Acknowledgements}

The author is grateful to CSIR, New Delhi for financial assistance.

\section{References}

Arora, G.S. and M. Chadhury (1982). On the lepidopterous fauna of Arunachal Pradesh and adjoining areas of Assam in North-East India: Arctiidae. Zoological Survey of India Technical Monograph 6: 66pp. Hampson, G.F. (1894). Fauna of British India moths, including Ceylon and Burma, Moths. Taylor and Francis Ltd., London, 690pp.

Hampson, G.F. (1900). Catalogue of the Lepidoptera Phalaenae in the British Museum, 2: 590pp.

Hampson, G.F. (1914). Catalogue of the Lepidoptera Phalaenae in the British Museum. Supplement to Catalogue Phalaenae, 858pp.

Kishida, Y. (1991). The genus Cyana (Lep. Arctiidae) from Philippinines. Tinea 13(8): 61-70.

Roepke, W. (1944). Revisional notes on the genus Cyana Walker (Lepidoptera: Lithosiinae). Tijdschrift voor Entomology 87: 26-36.

Watson, A., D.S. Fletcher and I.W.D. Nye (1980). The Generic Names of the Moths of the World. Noctuoidea, 228pp. 


\section{Key to differentiate Cyana Walker and Chionaema Herrich Schäffer}

1. Forewing with white ground colour having red or orange bands; male genitalia with valvula ending well below cucullus, saccus narrow, aedeagus with well packed patch of prominent spines and denticles; female genitalia with ductus bursae having anterior half sclerotized and posterior half membranous...

Chionaema Herrich Schäffer

1A. Forewing with aberrant colour pattern; male genitalia with cucullus ending well below valvula, saccus broad, aedeagus with a circular shield with denticle like cornuti; female genitalia with ductus bursae short and well sclerotized

Cyana Walker

\section{Key to the species of genus Chionaema Herrich Schäffer}

1. Forewing with terminal yellow band; hindwing with ground colour crimson; abdomen brick red; male genitalia with uncus pointed at tip bellissima (Moore)

1A. Forewing without terminal band; hindwing with ground colour white, suffused with crimson; abdomen not brick red; male genitalia with uncus not pointed at tip

2. Hindwing with veins $\mathrm{M}_{2}$ and $\mathrm{M}_{3}$ highly stalked from lower angle, $\mathrm{Cu}_{1}$ before lower angle of cell; male genitalia with aedeagus having anterior tip broad, narrowing gradually towards distal ..... catorhoda Hampson

2A. Hindwing with vein $\mathrm{M}_{2}$ arising from above lower angle, veins $\mathrm{M}_{3}$ and $\mathrm{Cu}_{1}$ stalked from lower angle of cell; male genitalia with aedeagus almost of equal width

3. Collar and tegula edged with crimson scales; forewing with three black spots in both sexes; crimson bands on forewing; female genitalia with corpus bursae globular, signum missing or single signum present

3A. Collar and tegula edged with scarlet scales; forewing of male possess three black spots and that of female with one spot; scarlet bands on forewing; female genitalia with corpus bursae oblong, bulb-shaped, a pair of signa present.

4. Forewing with a yellow streak just below costa interrupting post-medial band; tarsi banded with white and orange scales; male genitalia with uncus having rounded tip; saccus thick-walled; female genitalia with corpus bursae having a clad-like signum, ductus bursae with anterior half sclerotized and posterior half membranous obliquilineata Hampson

4A. Forewing with a black streak beyond postmedial band; tarsi banded with white and fuscous scales; male genitalia wit uncus having beak-like-tip;saccus thin walled; female genitalia with corpus bursae without signum; ductus bursae membranous dudgeoni Hampson

5. Labial palpus decorated with crimson scales; forewing with orange streak below costa beyond postmedial band; male genitalia with cucullus extending beyond valvula; saccus thin walled; aedeagus having vesica without denticles; female genitalia with anterior apophyses slightly shorter than posterior ones puella Drury

5A. Labial palpus with first segment decorated with white scales, but second and third having black; forewing with a brownish mark beyond postmedial band; male genitalia with cucullus and valvula reaching same level; saccus thick walled; aedeagus with vesica armed with numerous denticles; female genitalia with anterior apophyses, less than half the length of posterior ones alborosea (Walker) 